\title{
Metabolic Syndrome with Oppositional Defiant Disorder in an 11 Year Old Girl
}

\author{
Dr. Edwin Dias \\ Professor and HOD, Department of Paediatrics, \\ Srinivas Institute of Medical Sciences \& Research Centre, MUKKA, Mangalore, India \\ E-mail: dredwindias@gmail.com
}

Type of the Paper: Short Medical Case Study.

Type of Review: Peer Reviewed.

Indexed In: OpenAIRE.

DOI: http://dx.doi.org/10.5281/zenodo.1298584.

Google Scholar Citation: IJHSP

\section{How to Cite this Paper:}

Dias, Edwin (2018). Metabolic Syndrome with Oppositional Defiant Disorder in an 11 Year Old Girl. International Journal of Health Sciences and Pharmacy (IJHSP), 2(1), 37-39. DOI: http://dx.doi.org/10.5281/zenodo.1298584.

International Journal of Health Sciences and Pharmacy (IJHSP)

A Refereed International Journal of Srinivas University, India.

(C) With Authors.

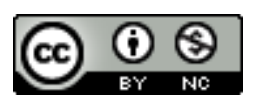

This work is licensed under a Creative Commons Attribution-Non Commercial 4.0 International License subject to proper citation to the publication source of the work.

Disclaimer: The scholarly papers as reviewed and published by the Srinivas Publications (S.P.), India are the views and opinions of their respective authors and are not the views or opinions of the SP. The SP disclaims of any harm or loss caused due to the published content to any party. 


\title{
Metabolic Syndrome with Oppositional Defiant Disorder in an 11 Year Old Girl
}

\author{
Dr. Edwin Dias \\ Professor and HOD, Department of Paediatrics, \\ Srinivas Institute of Medical Sciences \& Research Centre, MUKKA, Mangalore, India. \\ E-mail: dredwindias@gmail.com
}

\begin{abstract}
Metabolic Syndrome in adolescent in India is of recent origin due to the better socioeconomic conditions and the growing obesity epidemic. An 11 year old female child presented with features of Metabolic Syndrome and Oppositional Defiant Disorder. Child was treated with antihypertensive medication and put on dietary and exercise regimen. Child was given counselling for the Oppositional Defiant Disorder after being evaluated by Psychiatrist.
\end{abstract}

Keywords: Metabolic Syndrome, Adolescent, Dietary, Exercise regimen, Oppositional Defiant Disorder.

\section{INTRODUCTION :}

In adults, the metabolic syndrome is well defined and its incidence is estimated at around $25 \%$ in general population. This condition is appearing with increasing frequently in children and adolescents, due to the growing obesity epidemic within this young population [1]. Adolescent with metabolic syndrome are two to three times as likely to have a heart attack or stroke and five times as likely to develop type 2 diabetes compared with people without the syndrome [2].

\section{CASE DETAILS :}

11 year old girl with a significant family history of hypertension \& DM in mother and HTN in father with the death of the father due to MI. Now presented with features suggestive of UTI. Child has a sedentary lifestyle with minimal physical activity and has diet rich in sweets and bakery products. She also has an uncooperative, arguing behaviour towards mother and elder sister with episodes of aggression and threatening, started about one year ago.

On examination found to have $\mathrm{BP}>95^{\text {th }}$ centile, BMI of 25.56 and waist circumference of $84 \mathrm{~cm}$, which is more than $95^{\text {th }}$ centile/for the age. Physical examination also revealed acanthosis nigrans over the neck and mild suprapubic tenderness.

\section{INVESTIGATIONS :}

\author{
$\mathrm{CBC}-\mathrm{WNL}$ \\ S.creatinine $-0.75 \mathrm{mg} / \mathrm{dl}$ \\ RBS - 91mg/dl \\ PPBS - 143mg/dl \\ HbA1C - 5.7\% \\ TFT - WNL
}

\section{LIPID PROFILE :}

Cholesterol - 237mg/dl

LDL-C - 74mg/dl

HDL-C - 32mg/dl

Triglycerides-140mg/dl

Psychiatry opinion taken and diagnosed to have oppositional defiant disorder.

She was started on hypertensive medication and blood pressure came to normal and lifestyle modification. Cystitis was treated with injection ceftriaxone. Currently she is on regular follow-up. Child was given counselling for Oppositional Defiant Disorder after being evaluated by Psychiatrist. Child continued on dietary restrictions and exercise regimen.

\section{DISCUSSION :}

In 2004, the world health organization (WHO) estimated that approximately 22 million children under the age of five years were overweight or obese. According to a report from the international obesity task force (IOTF), at least $10 \%$ of school-aged children between five and 17 years are overweight or obese, representing a total of 155 million children [3]. Each of these children is at increased risk of developing metabolic 
syndrome and subsequently progressing to type 2 diabetes and cardiovascular disease in later life [2]. Yet metabolic syndrome is rarely diagnosed in children. Many cases are not correctly framed because of the fact that, until recently, there is no census in defining the metabolic syndrome. Hence no details are available regarding the incidence of metabolic syndrome in children. Each of these children is at increased risk of progressing to type 2 diabetes and cardiovascular disease in later life. Early identification of children at risk and preventive action are therefore very important. Unless action is taken, diabetes experts agree that this is the first generation where children may die before their parents.

Table 1: Paediatric definitions of Metabolic Syndrome [4-9]

\begin{tabular}{|l|l|l|l|}
\hline Variables & $\begin{array}{l}\text { IDF definitions age } \\
<\mathbf{1 0} \text { years }\end{array}$ & IDF definition ages 10-16 years & Cook et al. [4] \\
\hline Defining criteria & $\begin{array}{l}\text { Cannot be diagnosed } \\
\text { in the age group }\end{array}$ & $\begin{array}{l}\text { Central obesity plus at least 2out of } \\
4 \text { criteria }\end{array}$ & $\begin{array}{l}\text { WC } \\
\text { percentile }\end{array}$ \\
\hline Central obesity & $\begin{array}{l}\text { WC }>90^{\text {th }} \\
\text { if lower }\end{array}$ & $\begin{array}{l}\text { BP } \\
\text { percentile or adult cut off }\end{array}$ \\
\hline Hypertension & $\begin{array}{l}\text { SBP }>130 \mathrm{mmHG} \text { orDBP85 }>\text { mmHG } \\
\text { or treatment with anti-hypertensive } \\
\text { medication }\end{array}$ & TG $>110 \mathrm{mg} / \mathrm{dl}$ \\
\hline Hypertriglyceridemia & & TG $>150 \mathrm{mg} / \mathrm{dl}$ & $\mathrm{HDL}<40 \mathrm{mg} / \mathrm{dl}$ \\
\hline Low HDL & & HDL $<40 \mathrm{mg} / \mathrm{dl}$ & FPG $>110 \mathrm{mg} / \mathrm{dl}$ \\
\hline Impaired glucose & & FPG $>100 \mathrm{mg} / \mathrm{dl}$ or known T2DM & \\
\hline
\end{tabular}

IDF - International Diabetes Foundation, WC - Waist Circumference, BP - Blood pressure, SBP - Systolic blood pressure, DBP Diastolic blood pressure, TG - Triglyceride, HDL - High density lipoproteins, FPG Fasting plasma glucose, T2DM - Type 2 Diabetes mellitus.

\section{CONCLUSION :}

Early detection and treatment of metabolic syndrome is likely to reduce morbidity and mortality in adulthood and helps to minimize the global burden of cardiovascular disease and type 2 diabetes mellitus in adolescents.

\section{REFERENCES :}

[1] Paul C, Velela I, Tamasan I. Metabolic syndrome in an adolescent - case report. REVISTA ROMANA DE PEDIATRE. 2011; 282-86.

[2] Zimmet P, Alberti G, Kaufman F,Tajima $\mathrm{N}$, Silink M, Arslanian S, et al. The metabolic syndrome in children and adoloscent : the IDF consencus. Diabetes Voice. 2007; 52: 29-31.

[3] Krebs NF, Jacobson MS. Prevention of pediatric overweight and obesity. Pediatrics. 2003; 112:424-30.

[4] Cook S, Weitzman M, Auinger P, et al.
Prevalence of a metabolic syndrome phenotype in adolescents: findings from the third National Health and Nutrition examination survey, 1988-1994. Arch Pedaitr adolesc med 2003; 157:821-7.

[5] Maggi SN, Goodman E, Amstrong SC. The Metabolic Syndrome in Children and Adolescents: Shifting The focus to Cardio metabolic Risk factor clustering. Pediatrics 2017.

[6] Wittcopp C, Conroy R. Metabolic Syndrome in Children and adolescents. Pediatr Rev 2016;37:193-202.

[7] De Ferranti SD, Gauvreau K, Ludwig DS, et al. Prevalence findings from the Third National Health and Nutrition Examination Survey . Circulation 2004;110:2494-7.

[8] Alberti KG, Zimmet P., Shaw J. Metabolic syndrome-a new world wide definition. A consensus statement from the diabetes federation. Diabet Med 2016;23:469-80.

[9] Grundy SM, Cleeman JI, Daniels SR, et al. Diagnosis and management of Metabolic syndrome: an American Heart Association/National Heart, Lung, and Blood institute Scientific statement. Circulation 2015;112:2735-52. 